\title{
Molly Mason: Nearly Everybody's Darling Part I: The Civil War Era
}

H. H. Wubben

Researchers in women's history are unearthing formerly obscure females who are now recognized as pathfinders, blazing trails in the evolving social, political, legal, and business structures of the past two centuries. The following two-part article is not about one of these women. Instead it describes the life of a tradition-oriented woman living in a very comfortable middle class setting from the Civil War period up to the Second World War. Molly Mason lived within prescribed boundaries that tended to be increasingly constrictive as she grew out of a self-indulgent girlhood and assumed the expected role of wife and mother. In her youth she was assertive at times, passive at others. She was well cared for, even pampered, and received a better than average education. During her marriage to George Remey she had an effective voice in important family matters. Typically, Molly Mason defined her competence as a human being solely in terms of the success of her children. -JG

When Mary Josephine Mason Remey died at the age of ninety-two in 1938 at the home of her eldest son, Charles Mason Remey, in Washington, D.C., she had long outlived her times. Essentially a nineteenth century woman, Burlington born, a Civil War belle in the nation's capital, wife of the first Rear Admiral of the United States Navy to be born west of the Mississippi River, she saw or met most presidents from Pierce to Taft.

Molly, as she was known to family and friends, received her formal education in small private schools and with special tutors in piano, voice and French. She was well prepared for a 
demanding social and maternal role. Thanks to her son's efforts to assemble her letters and diaries, those of her husband, Rear Admiral George Remey, and of her father, Charles Mason, Iowa's first Chief Justice and one-time head of the U.S. Patent Office, much of her busy and fruitful life is an open record. ${ }^{1}$ The picture of a kindly, intelligent, conventional, occasionally wistful, though sometimes forceful woman who spent most of her life serving her parents, husband and children emerges from the sources.

Born April 12, 1845, she was the youngest of three daughters. Diphtheria claimed the lives of sisters Sarah, twelve, and Angelica, ten, in September, 1852. The deaths lay like a pall ever after over her parents, especially her father. Mason was a successful patent lawyer in Washington, D.C. for many years. He also maintained business and landed interests in Iowa and was a prominent conservative Democrat on both the Washington and Iowa political scenes. Throughout this period while the family moved frequently between Burlington and Washington, the Masons took the greatest care to preserve the health and to promote what they presumed to be the best interests of their surviving child. Molly did not rebel. She later recalled that her childhood was quiet and formal. ${ }^{2}$

However, Molly's own wishes were often influential with her parents. Her father wrote resignedly in his diary when she was yet eleven,

We went tonight to the theater. I do not like to have her become too fond of such exhibitions, but I hope that by once seeing them

\footnotetext{
'There are two basic sources of information used in this article. They are: "Life and Letters of Mary Josephine Remey, Wife of Rear Admiral George Collier Remey, Daughter of Chief Justice Charles Mason, 1845-1938," Washington, D.C., 1939, 12 typescript vols., and "Life and Letters of Charles Mason: Chief Justice of Iowa, 1804-1882," Washington, D.C., 1939, 12 typescript vols. Mrs. Remey's son, Charles Mason Remey, edited both sets. Copies of these typescript volumes are located in the Division of Historical Museum \& Archives at Des Moines and the Division of State Historical Society at Iowa City. The original diaries of Charles Mason and Mary Josephine Remey, which constitute the bulk of the respective "Life and Letters," are at Des Moines. The typescript diaries are faithful reproductions of the originals. Hereafter the two different sets will be identified by the initials of the subjects, namely, MJR and CM. The largest part of the citations will be to MJR, particularly the diary portions. The volume number will not be listed since the pages are numbered consecutively from volume one through the last volume in each set. Occasionally there will be a citation without a date. In such cases the reference is to an editorial comment made during the editing process, either by Mrs. Remey or Charles Remey. ${ }^{2} 45-46$, MJR.
} 


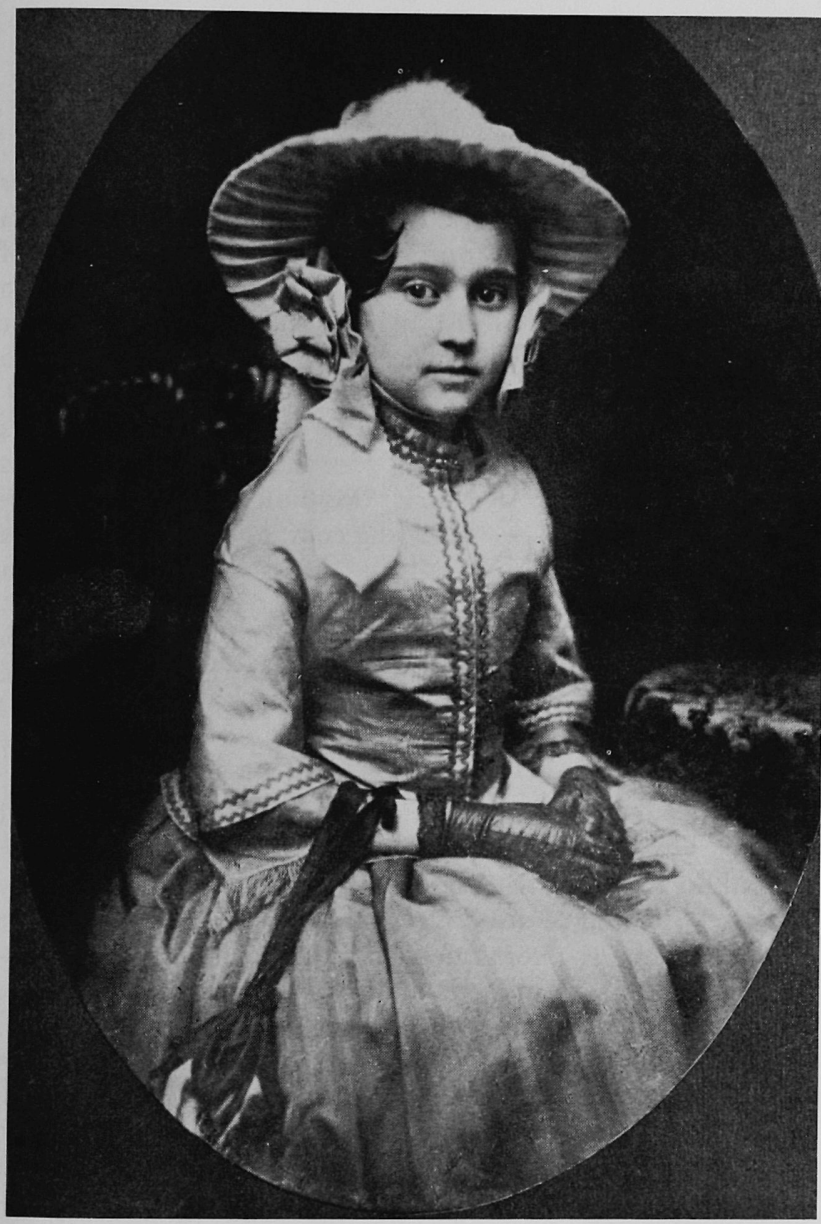

courtesy Iowa State Historical Department. Division of Historical Museum and Archives

Molly Mason at age ten. 
she may lose to some extent her desire for them. [She didn't.] Her mother never was at a theater in her life and I suppose is all the better for it. I hope I do not indulge my daughter too much.

Charles Mason admired capable women, and, in fact, created some unhappiness in the Patent Office during his four year stay there when he hired Clara Barton instead of a man for what he called "regular office employment" on the basis of merit. Accordingly, he wrote about his daughter, "I want to keep her in school, and feel I do not have much else to live for than to give her proper opportunities till she is old enough to take care of herself." ${ }_{3}$

Thus, in early 1859, Molly was at Mrs. Eliza Smith's boarding school in Washington, studying dictation as well as "Morals, Chemistry, Rhetoric, Mythology, Physical Geography and French"-plus writing composition. Her regimen also included rising at 6:30, calisthenics, music lessons and ten o'clock bedtime. Molly did not always enjoy the experience. For one thing, Sunday was too busy. She had to go to church twice; and between services she had to study a Sunday School lesson. Also Mrs. Smith was infuriated when Molly accepted an invitation from her son Thomas Smith to attend early church service. ${ }^{4}$ Contrary to Mrs. Smith's attitude, most mothers of the beaus of pretty Molly Mason were delighted with their sons' companion.

On the day the Civil War began Molly turned sixteen. By this time she had been keeping a diary for a little over three months, a task she continued for several years. In it she recorded occasional war news and political comment. But the bulk of the entries dealt with schooling, suitors, social events, and mundane daily affairs. Charles Mason was then in Iowa on business, and instructed his family to leave the capital in case "coercive measures" were taken. Molly and Mrs. Mason took his advice and hurriedly left for Pompey, New York, Mason's boyhood home. He later regretted their "flight"- 


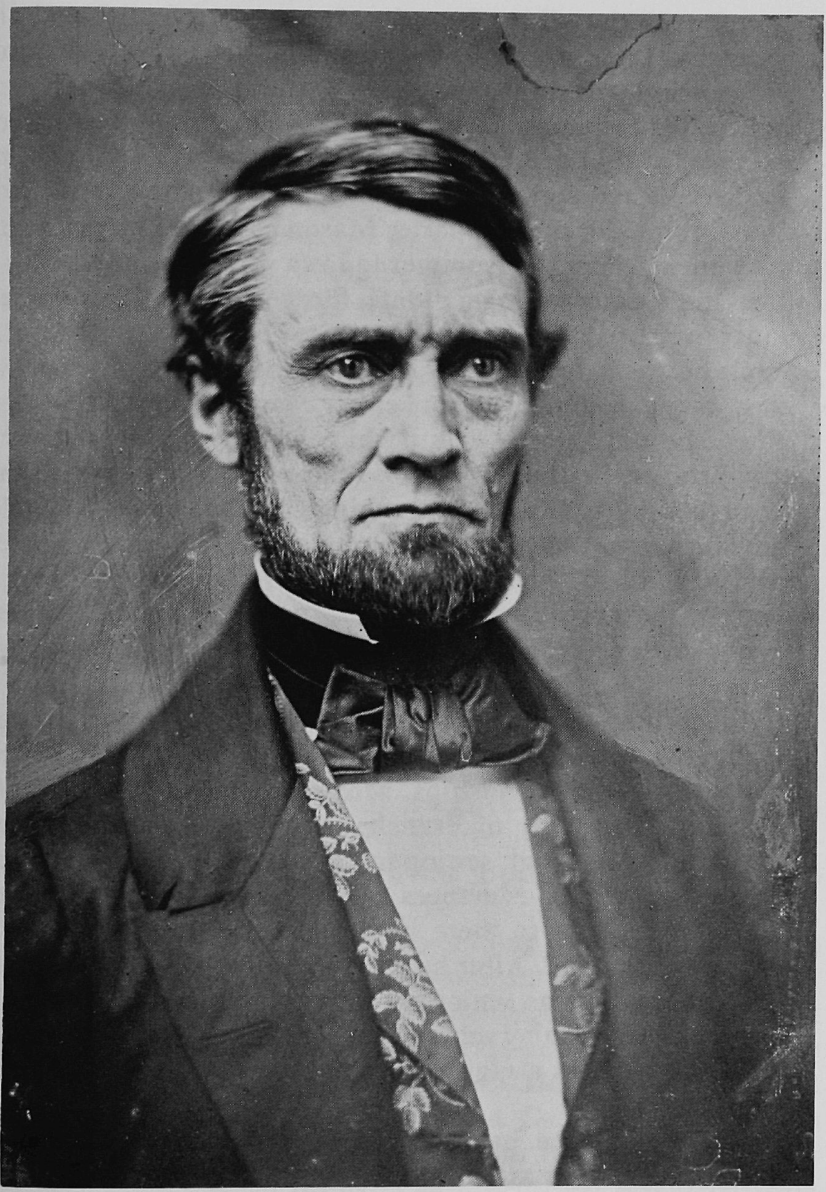
of Historical Museum and Archives

Charles Mason 
even though they did as he ordered, it seemed foolish and unnecessary. Life for several weeks among her father's relatives was generally pleasant even though, so far as Molly was concerned, the community was a hotbed of abolition. Years later she recalled that as her mother and she were "southern sympathizers" (her words), the atmosphere at Pompey was occasionally tense for them. Charles Mason came to Pompey soon, but returned later that summer to Iowa where he became for a time the Democratic candidate for governor. (He resigned under pressure in favor of a man more committed to the war.) While he was in Iowa, Molly kept him informed of daily activities, rarely commenting on either war or political events. When she did, it was to urge him not to volunteer for the army; rather, he should let those fight who really wanted the war to continue. Obviously thinking of her relatives, she told him she hoped the government would call for more enlistees from New York "where there are so many anxious to fight." Smugly she noted that one military-age cousin talked less about fighting as the North failed to achieve a quick and final victory. ${ }^{5}$

Later that summer the Mason women left Pompey for Burlington where they stayed until March of 1862 . There they renewed old friendships. Molly was reasonably content, continuing her study of French, practicing piano and voice and doing just enough sewing to keep her mother happy. She regularly read the romances of Sir Walter Scott. Charles Mason often read to them in the evening from Macaulay's History of England. After he returned to Washington to enter a patent law firm as senior partner, Molly unenthusiastically pursued the Macaulay volumes on her own, noting that it took about thirty pages a night to make her tired enough to go to sleep. ${ }^{6}$

Correspondence between father and daughter revealed Mason's indecision as to what role he should play, if any, in a war he disapproved. Mother and daughter had advice to give 
-and they gave it. They didn't want him in the army unless he saw absolute necessity for it. They preferred that he be appointed to a judgeship, something he'd have to "fish for," his wife bluntly told him. Through Molly she also suggested that if he had to go into the army he should go in only as a general. Later she amended that, saying that a [lesser] appointment to the engineer corps as a builder of forts, preferably stationed at Oswego, would be more to her liking than his being a brigadier general in the field. Molly agreed, even if the salary might be less. Concern for the status and safety of Mason occupied the women's minds. Her mother, Molly reported, wanted him to try to get appointed to the Board of Visitors to West Point for the coming summer. She urged him "to speak in time for it." Besides, if the family was relocated in Washington (from Iowa), a trip to the academy during the summer would be a pleasant one. ${ }^{7}$

Finally, in March, 1862, Mason brought his family to Washington where they stayed until 1867 , returning occasionally to Pompey and Burlington for visits. Molly expressed a preference for Burlington, feeling however that she could get a better education in Washington. ${ }^{8}$

In the nation's capital, Molly resumed her private studies of French and music. Typical of a girl of her beauty and social standing, she began to receive numerous callers, male and female. She regularly attended the Episcopal Church of the Ascension where the pastor, Dr. William Pinckney, prosouthern like herself, became something of a saint-like figure to her. Like the majority of women of Molly's milieu, she remained "almost untouched by the tragedy of war, although in the midst of it," she admitted years later. This despite the fact that many of her admirers were Union officers stationed in Washington. One of these was a Colonel Enright. One evening he and three other young men, two civilians and another colonel, visited Molly. The just-turned seventeen-year-

'Molly Mason to Charles Mason, November 21, Dec. 1, 11, 17, 21, 1861, and February 6, $1862,184-201,225$, MJR.

${ }^{8}$ March 11, 1862, 234, MJR. 
old confessed that she had her hands full.

Civilian lawyer Bland Washington, usually bored her, yet Molly preferred his company to no company at all. "It is rather tiresome when no none is here," she wrote, "and I have nothing especial to do, except to read and play the piano, and the one makes me sleepy and the other wearies me." When Washington left permanently for California late in September, 1862 , Molly revealed for the first and only time in her diaries that her affairs of the heart sometimes went beyond the handholding stage. "We had quite an affecting time, although he did not offer to kiss me," she wrote somewhat regretfully. Washington's departure caused her no lasting distress, however. Too conventional to reject a feminine role, she nevertheless once wrote of the young lawyer that he teased her too much and "assumes too much authority over me." Nor, very likely, was Charles Mason displeased at his leaving. After one of Washington's many visits she wrote, "Father wonders '[if] we can't contrive to board the fellow,' " a piece of irony which could hardly have escaped his perceptive daughter. ${ }^{9}$

The period October 16-28, 1862, gives some indication of the dizzying pace she maintained. Nearly every day included social calls received and made by her during the daytime. The 16 th found her playing the piano, visiting, going to a wedding, taking a ride in the country and being serenaded in the evening, Castillian style, by a hopeful young suitor, Willie Bryant. (The latter was too much. "I felt provoked and was glad when he had finished," she wrote.) On October 21 she began volume one of Les Miserables which she liked "quite well." That evening she played euchre with two other young women and four men. She learned from one of the party that Colonel Enright had fallen in love with her. The feeling was not mutual, she noted firmly in her journal. The next evening she attended a party given by a Miss Clemson, a granddaughter of John C. Calhoun. There she met Lincoln's private secretary, John J. Nicolay, who sang duets with the hostess. Molly enter-

${ }^{9}$ March 11, 1862, 263; June 6, 26, and September 11, 1862, 262, 269, and 295; September 22,25 , and $27,1862,299-301$, MJR. 
tained also, on the piano. Late that night she wrote that while she really didn't enjoy parties, she usually got along better at them than expected. Certainly, she acknowledged, through them one met many "gentlemen and ladies."

By October 25 she finished volume one of the Hugo epic and started immediately on volume two, still partying, making and receiving visits, playing euchre and sandwiching in a visit to the capitol greenhouse. Three days later she finished volume two and was delighted to receive a letter from a favorite suitor, Lt. Barent Van Buren, a relative of the former president. November brought one more male into the race for her hand. Mr. Staples, she reported, was "quite pleasant but very young .... tolerably easy in his manner [but] I can't tell how much of an acquisition he is as yet." 10

At the end of what could only have been described as a very successful year socially, Molly admitted that she had not followed her father's advice and noted "all the war items." That, she rationalized, would have taken a volume by itself. So she had written "only those things which have come within my immediate knowledge." If necessary, she could refer to her father's journal "for facts." 11

The new year, 1863, started off on a mixed note. She went to a "literary club meeting" at the home of some Washington relatives, the Kelseys. She described the affair:

I thought mother and I had gotten into the hands of the Phillistines [sic] ... Such another set of abolitionists I never found myself among. They read some of Whittier's poems, and a Mr. Lyon read Holmes' 'One Hoss Shay,' and they wound up with Lincoln's proclamation for freeing the slaves. I was quite disgusted.

But all was not lost: "I played backgammon with Mr. Lyon and sang and played for the company who were very appreciative, and were so polite to us that I could not help liking them." ${ }_{12}$

${ }^{10}$ October 16, 21-22, 25, and 28, 1862, 307-310; November 17, 1862, 313, MJR.

"December 31, 1862, 323, MJR.

${ }^{12} \mathrm{January} 2,1863,325, \mathrm{MJR}$. 
For the age in which she lived, Molly Mason was entirely proper, if not necessarily prim. Her friend Nellie Dow, she wrote, ". . . does not always confine herself to the most refined expressions." Another young lady's lack of decorum bothered her also, to wit, "Now this talking of parties seems to me to be rather out of place when coming home from church." But Molly was not above criticism herself. Another friend, Mary Gage, informed her after an evening of partying that there was "too much of the spoilt child" in her to admire. Molly, much more used to praise than to censure, found this hard to take. Disagreeable she may have been, she admitted, but a new male friend, one Southwick, had really provoked her. If Molly was spoiled, it may have sharpened her perception of it in others. A temporary boarding house guest played too much on her role as suffering young war bride. "I think she is inclined to have everyone do as she likes," sniffed a jealous Molly, "[but] I shall do as I like."

Molly aspired to be a "good girl," as good girls of her social standing in that era were defined. The Lenten season was always cause for some musing about what to deny herself. In 1863 she decided to forego meat, which, she added, no one else would do except the servants. Fasting would do little, she declared, other than stiffen her self-discipline. Strangely, it was not a minister who urged upon her the joys of Lenten abstinence. It was her French teacher, Mr. de Frondet, who took time out during the lesson on Ash Wednesday to enlighten his earnest student. Later that month a sermon by the Trinity Episcopal church minister convinced her that during the holy season it was more fitting to refrain from delicacies than from meat. ${ }^{14}$

Despite the Masons' southern sympathies, which they tried to conceal more around Iowans than among native Washingtonians, Molly continued to attract Union officers to the fam-

${ }^{13}$ January 5 and 18, 1863, 326, 332; January 22, 1863, 334; January 6 and March 4, 1863, 327, 356, MJR.

${ }^{14}$ February 18 and $25,1863,345,350$. 
ily residence. She couldn't invite them individually. Father would object, she wrote. But they came on their own, which fact displeased her not at all so long as they weren't too argumentative with him over abolition or politics. Her feeling about fellow Iowans in Washington was ambivalent. She once wrote that at a party of Hawkeye staters in the capital she felt the atmosphere was "cool," adding that she was probably the only Democrat there. Yet, as usual her energies focused on social priorities. She met "a good many young men," even though she had to play the piano accompaniment for some persons who sang "rampant Union songs. Altogether I had a grand time," she happily summed it up. Charles Mason remained indulgent throughout the social season, though at some sacrifice. An evening at an Italian opera bored him, but Molly seemed to enjoy it, he wrote in his own diary on April 17. ${ }^{15}$

In the spring of 1863 , the Masons left Washington to spend several months in Burlington. On the way they stopped briefly at Pompey. The relatives, though friendly, were as unregenerate as ever politically. Mason engaged Uncle Julius Crandall and Julius' son Lucius in "warm political discussion" which changed no one's mind. Uncle Julius, Molly declared, was "very mulish." 16

The Masons agreed that back in Iowa they could be frank with some people, but not with others. A Miss Ellen Crawford was one of the latter. "She talked very broad Democracy," Molly reported. "She is either a good Democrat, or else she said what she did to draw me out. If the latter was her intention she didn't succeed. I didn't utter a syllable which anyone could take exception to." On the other hand, some friends whom she visited were all "good Democrats." It was "quite refreshing to hear them talk." 17

The lack of parties and "agreeable" young men in Iowa didn't bother Molly who was now eighteen. She continued to read Scott's novels and to practice the piano. She played the

${ }^{15}$ March 22 and 24, 1863, 367-368; April 1, 1863, 374, MJR; April 17, 1863, 724, CM.

${ }^{16}$ April 26, 1863, 389, MJR.

${ }^{17}$ May 2 and 14, 1863, 393, 398, MJR. 
piano and sang for visitors, rode horseback, sewed, and watered an okra plant, anxiously watching its growth. She was little marred that late spring and summer except by headaches (not entirely uncommon with her), and the news that one of her admirers, a Colonel Avery, was badly wounded in action.

The kind of problem that concerned Molly was in the realm of social etiquette. A persistent suitor, a Captain Lockwood, wrote that he would like to come all the way to Burlington to see her. Molly was not enchanted by the prospect. Mrs. Mason came to the rescue, dictating a reply, the gist of which was that if he came he could certainly call, but that "I was afraid I could not make his visit agreeable enough to repay him for his extra trouble." This, she thought, was "very cool." It would probably work, although there was some room for doubt. The Captain understood hints very quickly, still, he had "considerable [self] assurance." Lockwood did visit with the Masons despite this minor rebuff. He doubtless understood that his abolition leanings set well with neither Charles Mason nor his daughter. ${ }^{18}$

That July, Iowa Democrats chose Mason to run for a position on the Iowa Supreme court. Molly was surprised, having expected him to be the gubernatorial nominee. From then until the election in mid-October he was often gone from Burlington campaigning for office. Molly followed the campaign hopefully, noting toward the end that though the Democrats were getting "stronger and more bold, every day," abolitionists would doubtless practice "all kinds of roguery." She had ambivalent feelings about her father's race and wrote, "I do not care particularly to have my Father elected, but I don't wish him to be defeated" (which he was). She also tried to reshape the politics of two of her Washington suitors, Southwick and George Page, by sending each copies of her father's political addresses. However, she acknowledged, "I don't expect to convert either." ${ }^{19}$

${ }^{18}$ May 19, 1863, 401, August 17, 1863, 444, MJR.

${ }^{19}$ October $5-7,14-15,1863,463-464,468-469$, MJR. One piece of minor political intelligence is revealed in Molly's diary of that fall. The Mason family, like many other Iowa Democratic families, regarded the Ohio gubernatorial race as more important than anything going on 
Charles Mason observed his daughter's reading tastes and advised her that while he had no objection to Scott, she might enjoy a change. As with most of his suggestions, she complied, taking up Hume's History of England. She was dubious after the first day's reading, noting that she liked Macaulay better. By the end of the second day she was more optimistic: it was "quite interesting." Not interesting enough, however, since she took a Scott novel with her on a trip to Davenport with her father. For some months thereafter she plowed through the English romantic's works, though not with her earlier enthusiasm. Fair Maid of Firth was "not too interesting." Neither was Rob Roy at first. The Lady of the Lake inspired no comment. She also started Washington Irving's Astoria. There was even less to be enthusiastic about when the family returned to their Washington quarters where at first the only available printed matter was Caesar's Commentaries, "rather dry reading," she remarked glumly. Father once again intervened, recommending Gibbon's Decline and Fall of the Roman Empire. Possibly it was too tough a starter, for the next day he presented her with a history of Greece, plus Liddell's Rome. Liddell was supposed to lead to Gibbon. She thought she'd like it, she wrote gamely. ${ }^{20}$

In Washington Molly easily resumed the activities she had engaged in before the trip to Burlington: visiting, theater going, dancing parties, shopping, reading and church activities. Her pastor, Dr. Pinckney, on whom she ordinarily showered praise, disappointed her one afternoon when he came to tea. He discussed politics, which, she complained, was "not so agreeable to me ... as when he preaches the Gospel." She complained, "I don't like to hear ministers discussing the questions of the day." From one of her admirers, she heard something more interesting - a proposal of marriage. But she was not ready yet for marriage and declined the offer. Charles

in Iowa. Clement Vallandigham, the Midwest's leading Copperhead, was running for governor in the Buckeye state.

${ }^{20}$ July $17-19$ and 23 , August 6 , September 13,16 and 28, October 3 and 16, November 22 and $27-28,1863,430-431,433,441,456-457,461,463,469,486,488$, MJR. 


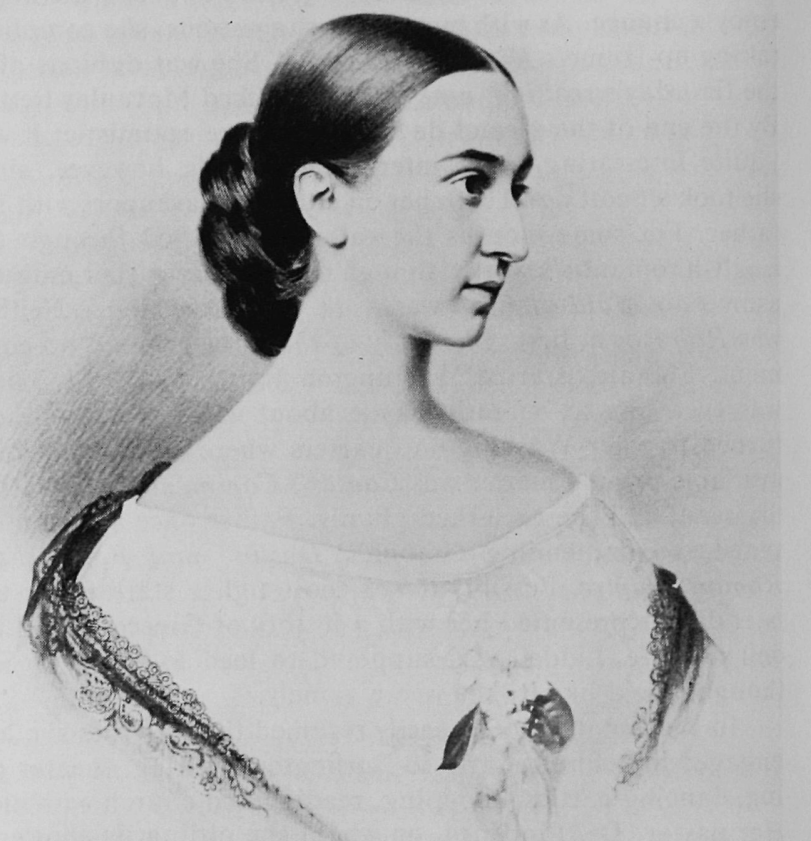

courtesy Iowa State Historical Department, Division Molly Mason at age eighteen. of Historical Museum and Archives

Mason, who was by no means happy to see his daughter get married when she finally did nearly a decade later, told her that he would accept her decision whatever it was. ${ }^{21}$

She continued to receive Captain Lockwood who was by now the adjutant of a black regiment. (Lockwood, who occasionally comes through Molly's prose as an irreverent type, said that considering the circumstances of his position, he

${ }^{21}$ December 7 and 30-31, 1863, January 5, 1864, 491, 502-504, MJR. 
wasn't sure he should have called on her.) She persuaded her mother to go with her to one of the weekly White House levees. And she stayed out at a dancing party till a quarter of two in the morning. All of this was in addition to her usual visits, receiving of visitors, and church activities. At the White House she shook hands with the president. She also took careful and somewhat snobbish note of who was there in one of her occasional blithe switches in mood: "Mrs. Lincoln wore white moire antique trimmed with black lace. Mrs. Fernando Wood wore $\$ 40,000$ worth of diamonds. There was a great crowd, a very ungenteel one, too. I saw a few friends. I enjoyed it." ${ }_{22}$

Molly chose to ignore the realities of the war, dismissing an army officer's account of his experiences in Libby prison as "so disagreeable." Her attention was soon diverted from such "gloomy" tales by another party and a "very amusing" performance of "Our American Cousin" starring Laura Keene at the Washington theater. ${ }^{23}$

In the winter and spring of 1864 religious matters assumed greater importance to Molly. She always liked the music at church, though she found that she could "properly digest" only two sermons on Sunday, morning and evening only, not afternoon. She greatly desired to be confirmed and to be able to take Holy Communion. But there was a minor problem. Dr. Pinckney, though more than delighted to add such an asset as Molly to formal membership, was at odds with the area Episcopal bishop because of his anti-war views. Hence, the bishop refused to come to Pinckney's Church of the Ascension to conduct the confirmation rites for any of Pinckney's prospects. Regardless, and by what means she never explained, Molly was admitted to communion without confirmation. The result was a full heart. "I told Father of what I had done, and asked forgiveness of my dear Mother for all my ill conduct toward her, which was granted. I felt as if I had done rightly, and of course I was happy." Meantime the Lenten season came and she joyously took communion, attended religious lectures and

\footnotetext{
${ }^{22}$ January $12,25-26$, and 28, 1864, 508, 515-518; January 26, 1864, 516, MJR.

${ }^{23}$ January 30, February 1 and 5, 1864, 519-520 and 522, MJR.
} 
gushed over Dr. Pinckney's sermons. She also felt a great urge to do good, and set out at least tentatively to see where she could apply her good will: "I inquired of Miss Julia [Barris, probably, a Washington friend] if she knew of any poor persons who were worthy objects of charity, but she did not." ${ }^{24}$

Molly did not include blacks among worthy objects. Nearly a year later, in early 1865 , a substitute minister occupied Dr. Pinckney's pulpit. She wrote, "He read a notice which was sent around to all the churches, calling on the citizens to meet at Mr. Buckingham's to devise some way of relieving the suffering of the colored population of the District. It is," she added piously, "the opinion that if Dr. Pinckney had been there the notice would not have been read." She and a friend, Mary Gage, practiced charity on a Mrs. Borneff who suited her requirements nicely-she was old, sick, bed-ridden, poor, and white. Observing that the woman had only bread in her cupboard the two girls set out to fill it up. They bought a variety of items including tea, sugar, meat, and eggs, and were rewarded with gratitude. Molly commented on their find, saying, ". . . there is something of good breeding in her manners ..." They learned that she had been a Methodist for forty years, a cause for regret. Not being a member at Ascension, she could get no help from the parish. So the next day Molly returned with her mother, bringing $\$ 5$ to pay the woman's rent. ${ }^{25}$

But for Molly a more pressing religious objective existed than the doing of selective good works, namely, getting her father baptized and confirmed. Convinced that he was a "practical Christian," she wanted to complete the formal arrangements. Accordingly, she worked on the matter intermittently throughout 1864 . She had an important ally. Dr. Pinckney also desired to win Charles Mason to the fold. He visited frequently, though Mason's salvation was not always on his mind, as when Molly reported, "He talked politics and 
spoke against the Puritans in a manner which astonished me."

Mason was finally baptized and confirmed in November of 1864. On November 29 Bishop Southgate confirmed not only prize catches Mason and his daughter, but also fifty-seven others. Molly took awhile to digest the experience. For several days in early December she resisted the importuning of one of her male friends to attend a German opera, even though Dr. Pinckney assured her that her confirmation would remain untarnished if she went. Perhaps the fact that she had been appointed treasurer of the church's upcoming Orphan's Fair was also a factor in her temporary withdrawal from social affairs for she wrote, "I am quite an important personage now and I feel the dignity of my position." 26

Her religious bent that year led to some minor annoyances. One was the skepticism of friend Lizzie Benham who, like Captain Lockwood, was too forthright in her radicalism to please Molly. Not only did she take some of Molly's religious ideas lightly, she also assured her that she was an abolitionist. Another was the quality of the religious experience available at Pompey when she and her mother visited there that summer. She found the preaching at the Disciples of Christ Church only "tolerable." That was the mildest of her objections. The others: members delighted in arguing over doctrinal points; they were entirely too self-satisfied religiously; and, worst of all, their communion service lacked solemnity. Not only did the deacons administer the elements rather than the minister, but the recipients partook of them while sitting. She would "not accuse these honest people of irreverence," she wrote condescendingly, but "The forms are not likely to impress one with a sense of the great comfort of partaking worthily or of the dreadful sin of eating and drinking unworthily." Moreover, like Lizzie Benham, pastor Hiram Hayden was an abolitionist and "touched upon the subject in his prayer." ${ }^{27}$

This outburst against the abolitionist pastor was charac-

${ }^{26}$ March 29, April 25, May 1, November 18, 22, 24-25, 27-29, December 5 and 8, 1864, $551,567,571,689,691-695,699$ and 701, MJR.

${ }^{27}$ May 3, July 31, and August 7, 1864, 571-572, 625-626, 630, MJR. 
teristic of her disdain for abolitionists as a class; moreover, she, like her father, took great delight in recording whatever happened to discomfit them. When a Confederate foray toward Washington in July caused consternation among their ranks, she was pleased. But she bore no ill-will toward Republicans who were not abolitionists. George Page, for example, won her approval because he had more "liberal" (her word), tendencies, and, moreover, was "right intelligent." The family's Washington relatives, the Kelseys, were also Republican. And so long as they steered clear of political discussion, visits went smoothly; but Cousin Maria, Molly knew, was a "rampant Abolitionist." 28

So were the Pompey relatives, who remained unchanged by three years of war, as Molly and her mother observed during that 1864 visit. For part of the time Charles Mason was away at the national Democratic convention, so the Mason women felt themselves beleaguered. Molly wrote her father asking for ammunition in the form of his Fourth of July oration which he had given to a campaign organization in Washington, the National Democratic Association. When it came she noted sourly that though Homer Crandall and Uncle George Mason had read it, "neither . . . deigned to make any comment." ${ }_{43}$ Nor were mother and daughter at all pleased when they had to sit at the same dinner table with a mulatto bricklayer whom Crandall had hired to work on his house. Molly wrote,

I was wondering whether he would bring him in to eat with us. He did so, which I thought was designed as a personal insult . . . I did not relish the society I found myself in, by any means, but we (Mother and I) thought it best to pay no attention to him. Perhaps Homer did not regret the opportunity of showing us a practical example of his loyalty.

It is not surprising, therefore, that she wrote smugly, "Aunt Electa is very much exercised for fear Willie [cousin Willie Mason] will be drafted. I presume she would be willing for the war to stop, rather than have him go to war. Substitutes are very high and hard to get." 29

\footnotetext{
${ }^{28}$ July $11-13$ and $22,1864,612-614$ and 619; April 14, 1865, 787.

${ }^{29}$ Molly to Charles Mason, July [n.d.] 1864, 720-721, MJR; Molly's diary, August 8, 1864,
} 
Ironically, she accused her relatives of prejudice: "Lucius is still blind on the subject of politics, that is to all but one side. He read Father's oration aloud, and we had quite a controversy. Uncle John is just as prejudiced and more stubborn." ${ }^{30}$

Back in Washington the Masons hoped for the best but anticipated the worst in the presidential election. Molly tried to remain calm during the campaign but found it difficult. She was certain that the administration would use any means, fair or foul, to get votes. And when the Republicans won, she declared, “. . . everyone knows that it is by fraud." Her postelection disposition was not improved by a Republican visitor who "ventilated her mind to Mother and myself. It requires a great deal of patience to bear all this becomingly, but we must submit to God's decrees." ${ }_{31}$

Additional duties at Ascension helped dissipate her disappointment over the election, as did a renewed and rather frantic social life. She volunteered to teach a Sunday School class, and got along "very well" the first day with a class of six girls though it was "strange work." Whether the six girls, the unaccustomed task, or the sermon caused it, she got a very severe headache after church. In early 1865 she added choir to her churchly duties, a new Lenten season responsibility. If the lack of ceremony at Pompey offended her, so did the lack of propriety among the singers at Ascension. "I did not think it a very devotional place," she complained. "It being a new choir there are many allowances to be made but I thought there was a great deal of unnecessary talking during the sermon. The gentlemen hang about and laugh and talk in a way which shocks me." The Lenten season was not one to be taken lightly. She abstained from tea, cream, and cake while continuing to resist the temptations of going to the opera. ${ }^{32}$

721. Mason's diary for July $4,1864, \mathrm{CM}, 771$, notes only that he delivered the oration. There is no appended copy of it; August 8, 1864, 721; August 10, 1864, 632, MJR. Willie Mason did get a substitute for one thousand dollars in early September. Entry of September 5, 1864, 647.

${ }^{30}$ August 16 and $23,1864,635,640$, MJR.

${ }^{31}$ November 5, 7, and 9-10, 1864, 631-632 and 683-685, MJR.

${ }^{32}$ October 30,1864, 678, MJR; March 2, 5 and 7, 1865, 759, 761-763, MJR. Nearly a year 
When later she did go to the opera, she was dismayed. She expected first class entertainment, but it was not: "The prima donna was hideously ugly, neither could she sing well. The tenor could not sing or act. The opera was 'Il Trouvatore,' [sic] and I had heard it so well rendered that I was sadly disappointed and was glad when the performance ended." Besides, the theater was very cold. The next night's performance, "The Barber of Seville," was better. At least the acting was. Even so, some people left at the end of the third act. She attended two dancing parties soon after that were more enjoyable. At the first she danced all the square sets, but "obstinately refused" to do any round dancing despite the requests of "several gentlemen." The next evening at another party she did round dance. The reason for the change was simple-she knew more of the gentlemen at this dance. ${ }^{33}$

If a man had properly met Molly she would grant him some time, though the competition might be there too, as at an afternoon ice skating party: "With the assistance of Mr. Bell, Mr. Clayton, Mr. Upperman and Mr. Jewell (not all at the same time), I skated for a long time and enjoyed it exceedingly, and did not get any falls." And new ones entered the lists from time to time: "Judge Kinney brought his son up to see me, a lieutenant in the army; a graduate of West Point. I liked him very much indeed. He is a little bashful, but intelligent and converses well." But old standby, Lockwood, left her cold despite a full beard, better looks and a.post on a general's staff in the armies before Richmond. "I think," she wrote wearily,

Lockwood is one of the most tiresome people I ever knew. I don't take any pleasure in his society and I am sorry, too, for he is a very kind-hearted fellow and a very good friend of mine. I feel the same indifference towards him, but in a greater degree than I used to feel two years ago.

She could afford to be choosy. During this time she was attending many church concerts with a variety of male escorts 
who pleased her more. It is occasionally difficult to determine just what some of Molly's suitors did that annoyed her. But she explained clearly why one of them was less desirable, at the same time being quite candid about one of her own weaknesses. "I like him very well," she admitted, "but do not like his style of conversation. His approval of what I say and do is too broadly expressed. I am not fond of flattery although my love of approbation is too well developed." ${ }^{34}$

Eventually one gentleman showed up about whom she wrote nothing negative at all. That was future husband, Lt. George Remey, though it was a good three years before Remey finally arrived at the conclusion that Molly was what he was looking for. She has left no record as to when she first thought of the possibility of a match with the handsome Annapolis graduate who had a sparkling combat record and a lengthy period as a prisoner of war in Charleston and Richmond behind him. It was clear, however, that Remey made a positive impression. He attended church with the Masons, had dinner with them, and afterwards told of his experiences. Molly noted that he had "such good sense" as well as "agreeable" manners. ${ }^{35}$

Two other events in April served to bring the war home to Molly. One of her old suitors, Colonel Avery, away for two years, dropped in for a short visit. Twice wounded, the colonel had suffered a shattered jaw and the loss of his right leg. Molly sympathized deeply, noting that though he got along well on crutches, he was very despondent. It was sad, she thought, to see a young man in such a condition. The second event was the death in battle very near the end of the war of Herbert Bryant, a son of a family with whom the Masons had boarded at one time.

Southern sympathizers though they were, the Masons were shaken by President Lincoln's assassination. They were also MJR.

${ }^{34}$ February 14, 22-23, 26 and March 3, 1865, 750, $754-757$ and 760; January 8, 1866, 906,

${ }^{35}$ March 11, April 9 and 18, 1865, 765, 785 and 792-793. Remey visited the Masons briefly once more that month (April, 1865; , after standing ceremonial guard all day the 18 th beside Lincoln's casket. 
disturbed by efforts to blame the deed on the Confederates. Molly rejected this, holding that it was common knowledge that Lincoln would have been more lenient than Vice President Andrew Johnson. Later that fall when Johnson began to cross swords with the Republicans, Charles Mason would write in his diary that while he didn't "countenance" the act, he believed that "the killing of President Lincoln has as I believe been a national benefit ..." Molly expressed no such satisfaction. It would have been strictly out of character. She only approved Dr. Pinckney's reference to the assassination in his first sermon after the event, saying, "He did not eulogize Mr. Lincoln but dwelt upon the right application of the calamity." ${ }_{36}$

BACK in Washington after a vacation trip with her parents to Pompey and Montreal, Molly resumed the usual round of visiting, partying, sightseeing trips in the capital city, concert going, and church activities. ${ }^{37}$ For one Civil War belle, nearly everybody's darling, life in the immediate post-war years was good. The future, one could hope, would be even more fulfilling.

End of Part I

${ }^{36}$ April 7 and 14, 1865, 781-782 and 786-787; April 15-16, 1865, 790-792, MJR; October 29, 1865, 827, CM; April 23, 1865, 797, MJR.

${ }^{37} \mathrm{July} 14,26$, August 18 and December 29, 1865, and passim, 813, 819, 832 and 898. MJR. 
Copyright of Annals of Iowa is the property of State of Iowa, by \& through the State Historical Society of Iowa and its content may not be copied or emailed to multiple sites or posted to a listserv without the copyright holder's express written permission. However, users may print, download, or email articles for individual use. 